\title{
Full-Scale Application of Up-flow High Rate Anaerobic Reactor with Substrate Modification and Effluent Recirculation for Sugarcane Vinasse Degradation and Biogas Generation
}

\author{
Nani Harihastuti ${ }^{1}$, Rustiana Yuliasni ${ }^{*}$, Silvy Djayanti', Novarina Irnaning Handayani', \\ Rame Rame', Adi Prasetio', Abudukeremu Kadier ${ }^{2}$ \\ ${ }^{1}$ Centre of Industrial Pollution Prevention Technology, Jl.Ki Mangunsarkoro No. 6, Semarang, Central Java, \\ Indonesia \\ 2 Laboratory of Environmental Science and Technology, The Xinjiang Technical Institute of Physics and \\ Chemistry, Key Laboratory of Functional Materials and Devices for Special Environment, Chinese Academy of \\ Science, Urumqi, 830011, China \\ * Corresponding author's email: rustianay@kemenperin.go.id
}

\begin{abstract}
This study was aimed at studying the potential of biogas (methane) production from vinasse wastewater in real full-scale application using a two-stage sequencing Up-flow High Rate Anaerobic Reactor (UHRAR), with effluent recirculation and substrate modification. A batch experiment was initially conducted prior to the full-scale application experiment. The batch experiment was done with experimental condition variable: undiluted sample $(\mathrm{pH}$ 6) and diluted samples (pH: 5; 6 and 7), while $\mathrm{pH}$ and methane production were observed for 50 days. Full-scale application was carried out in two-stage UHRAR reactors with volume $60 \mathrm{~m}^{3}$, HRT $40 \mathrm{~d}$ and OLR $60.1-104 \mathrm{~kg}$ $\mathrm{COD} / \mathrm{m}^{3} \cdot \mathrm{d}$. The observation lasted for $32 \mathrm{~d}$. The result from the batch experiment showed that the diluted samples achieved higher COD degradation and methane generation than the undiluted sample. The optimum condition occurred at $\mathrm{pH} 7$, with theoretical methane yield of 7.5-10.64 $\mathrm{L} \mathrm{CH}_{4}$ per $\mathrm{kg} \mathrm{COD}$. In turn, in full scale application, at day 32, COD removal was $71 \%$ (69.1 kg COD/d removed), with methane production was $36.72 \mathrm{~m}^{3} \mathrm{CH}_{4} / \mathrm{d}_{\text {. }}$ Methane production per COD removed was $0.53 \mathrm{~m}^{3} \mathrm{CH}_{4} / \mathrm{kg}$ COD $\cdot \mathrm{d}$. Substrate modification and effluent recirculation could improve the substrate biodegradability, maintain microbial diversity and enrich nutrients in the reactor.
\end{abstract}

Keywords: anaerobic digestion; biogas; $\mathrm{CaCO}_{3}$ addition; recirculation; vinasse wastewater

\section{INTRODUCTION}

The Indonesian sugar and ethanol industries have developed rapidly in recent years. Indonesia Biofuel Association indicated that ethanol production could reach 180 million liters per year, with average domestic consumption of 100 million L per year. Sugarcane has high potential energy, $40 \%$ transformed into alcohol, and $31 \%$ remain in the by-products as bagasse $(26 \%)$ and vinasse (5\%) (Del Nery et al., 2018). Vinasse is the by-product of the alcohol distillation process. The production of vinasse in a traditional alcohol factory is around 8-20 L per Liter of ethanol produced (Cabrera-Díaz et al., 2017; Joppert et al., 2017). Vinasse is characterized by a high concentration of organic matter (10-65 g BOD/1), nutrient salts (potassium (K) and sulfate), low $\mathrm{pH}(3.5-5.0)$, high temperature $\left(80-90^{\circ} \mathrm{C}\right)$, and permanent dark color (brown to black) (CabreraDíaz et al., 2017; Joppert et al., 2017; Marafon et al., 2020). The water and soil pollution resulting from sugarcane vinasse wastewater disposal is a challenging issue that comes from the biofuel ethanol industries (Harihastuti and Marlena, 2018).

Due to its high organic concentration and flowrate, sugarcane vinasse cannot be effectively treated by using conventional methods. A fullscale application that involves integrating several technologies should be applied to remove organic 
pollutants to the level that will comply with the effluent stream standard. Integration technology for treating vinasse wastewater should be started by converting organics into biogas to reduce the organic concentration and utilize the biogas (methane) for energy (Parsaee et al., 2019). Biogas production from vinasse has been studied extensively from laboratory scale to a full-scale application with mixed results (Christofoletti et al., 2013; Moraes et al., 2015; Reis and $\mathrm{Hu}, 2017$ ). Harihastuti et al. (2020a) scanned the potential of vinasse methane production on a laboratory scale and found that $51.7 \%$ of COD could be reduced and converted into methane during 42 days retention time. The methane production was $0.058 \mathrm{~L}$, converted from $180.95 \mathrm{~g}$ COD degradation. The methane production in the study was low because the $\mathrm{pH}$ in the reactor was also low (pH was 5.15.7), not optimum for the methanogenic activity. Low pH also encourages the Sulfur Reducing Bacteria (SRB) to grow and compete with methanogenic bacteria for carbon sources, thus hindering the methane generation. Carbon dioxide gas was also abundantly detected in the reactor headspace ( $>50 \%)$.

In an anaerobic system, the methane production rate is aligned with the substrate biodegradability potential. For a substrate with low biodegradability, such as vinasse wastewater, substrate pretreatment/modification is crucial to improve the potential of methane production (Mahajan et al., 2020). Substrate modification is performed via $\mathrm{pH}$ adjustment and alkalinity enhancement. In turn, $\mathrm{pH}$ was adjusted to 6.5 to 7.0 by adding some alkalinity (lime/calcium carbonate $/ \mathrm{CaCO}_{3}$ ) to ensure the growth of methanogenic bacteria (Hwang et al., 2004). The dilution of the substrate should also be conducted to reduce the suspension and solid and to improve the solubility/accessibility of substrate to microorganisms, thus enhancing biodegradability (Li et al., 2007). Effluent recirculation to dilute the substrate/influent is also significant to reduce the utilization of freshwater. Effluent recirculation is also beneficial to ensure the return of acidogenic bacteria into the anaerobic reactor, and improve the acidogenesis process vital for the formation of Volatile Fatty Acid (acetate, propionate, and butyrate). The building of VFA, specifically acetate, would allow the growth of methanogens. Beside substrate modification, anaerobic reactor modification is also used to enhance the methane production.
Up-flow Anaerobic Filter reactors have proven robust to treat some wastewater sources and required shorter retention time (Drtil et al., 2002; Yuliasni et al., 2017).

There were not many studies about the biogas potential from vinasse, particularly about the full-scale application. Souza et al. (2018) studied the performance of full-scale UASB for treating vinasse wastewater with Organic Loading rate (OLR) of $25-30 \mathrm{~kg} \mathrm{COD} / \mathrm{m}^{3} . \mathrm{d}$, with volume 75 $\mathrm{m}^{3}$ and HRT $10 \mathrm{~h}$. It could remove $72 \%$ COD with methane generation of $10 \mathrm{Nm}$ gas $/ \mathrm{m}^{3}$.d. However, this study and many others were operated in low to medium OLR (Fuess et al., 2017a). In reality, the vinasse wastewater could have a very high organic loading rate, between $80-150 \mathrm{~kg} \mathrm{COD} /$ $\mathrm{m}^{3} . \mathrm{d}$, which makes it very difficult to treat.

Therefore, the aim of this study was to test the potential of biogas (methane) production from vinasse wastewater in a real full-scale application using a two-stage sequencing Up-flow High Rate Anaerobic Reactor (UHRAR), combined with effluent recirculation and substrate modification. The initial substrate/influent will be modified by adding lime to enhance the alkalinity and dilute the influent with water to improve dissolved organic matters that are more accessible to microorganisms. Effluent recirculation was applied to enhance the acidogenesis process and supply the system with more nutrients. This study explored the degree of organic degradation, the amount of biogas produced (the quantity and quality), the optimum retention time achieved, and the quality of vinasse effluent after treatment.

\section{MATERIAL AND METHODS}

\section{Experimental set up}

The experiment was divided into 2 phases. The first phase was a batch experiment conducted in the laboratory. The batch experiment aimed to study the optimum $\mathrm{pH}$ for methane generation. The batch experiment was similar to the Biochemical Methane Potential (BMP) test. The second phase was a full-scale continuous running application.

\section{Batch experiment}

Three anaerobic bottles, with volume $1 \mathrm{~L}$, were used. To every bottle, $300 \mathrm{ml}$ mix cultures sludge and $700 \mathrm{ml}$ vinasse wastewater were 
added. Besides, nutrients in the form of urea and phosphorous were added with the ratio BOD: N: $\mathrm{P}=100: 2.5: 0.5$. Three samples were diluted with water, with ratio water: vinasse $=4: 1$, and the $\mathrm{pH}$ was adjusted to 5, 6 and 7 (the samples were identified as $\mathrm{pH} 5, \mathrm{pH} 6$, and $\mathrm{pH} 7$ ). One sample was undiluted but $\mathrm{pH}$ was adjusted to 6 . Lime was used to adjust the $\mathrm{pH}$. The experiment lasted for 50 days.

\section{Full-scale continuous running experiment}

Full-scale application was taken place in the traditional ethanol industry in Polokerto, Sukoharjo Central Java. Seeding was conducted by adding $20 \%$ of microbial seeds into the reactor, about $6 \mathrm{~m}^{3}$ in each dome. Microbial seeds were sludge derived from anaerobic digester, taken from a WWTP of the ethanol industry. Macronutrients were added with the ratio BOD: N: $\mathrm{P}=100: 2.5: 0.5$. After seeding, both UHRAR dome 1 and 2 (figure 1, C1 and C2) was filled with a mixture of water and vinasse with the ratio $4: 1$; pH was adjusted to 5-6 using lime until both domes were full and ran to the overflow chamber (Figure 1, Part D). The reactor was left for another seven days. After seven days, the reactor was operated with continuous running. In full-scale operation, vinasse wastewater with characteristic of $\mathrm{Q}=1.5 \mathrm{~m}^{3} / \mathrm{d}$, COD $60,990-104,000 \mathrm{mg} / \mathrm{L}$ and $\mathrm{OLR}=60.1-104$ $\mathrm{kg} \mathrm{COD} / \mathrm{m}^{3}$.d was pumped to the reactor every day for the duration of 34 days.

The operational procedure for continue running was: $1.5 \mathrm{~m}^{3}$ raw vinasse wastewater was filled in the mixing chamber (Figure 1A). In the mixing chamber, $\mathrm{pH}$ was adjusted into $5-6$ by adding a lime solution. The wastewater was streamed into the feeding chamber (Figure 1B). From feeding chamber, the wastewater runs to UHRAR 1 and 2 (Figure 1, C1, and
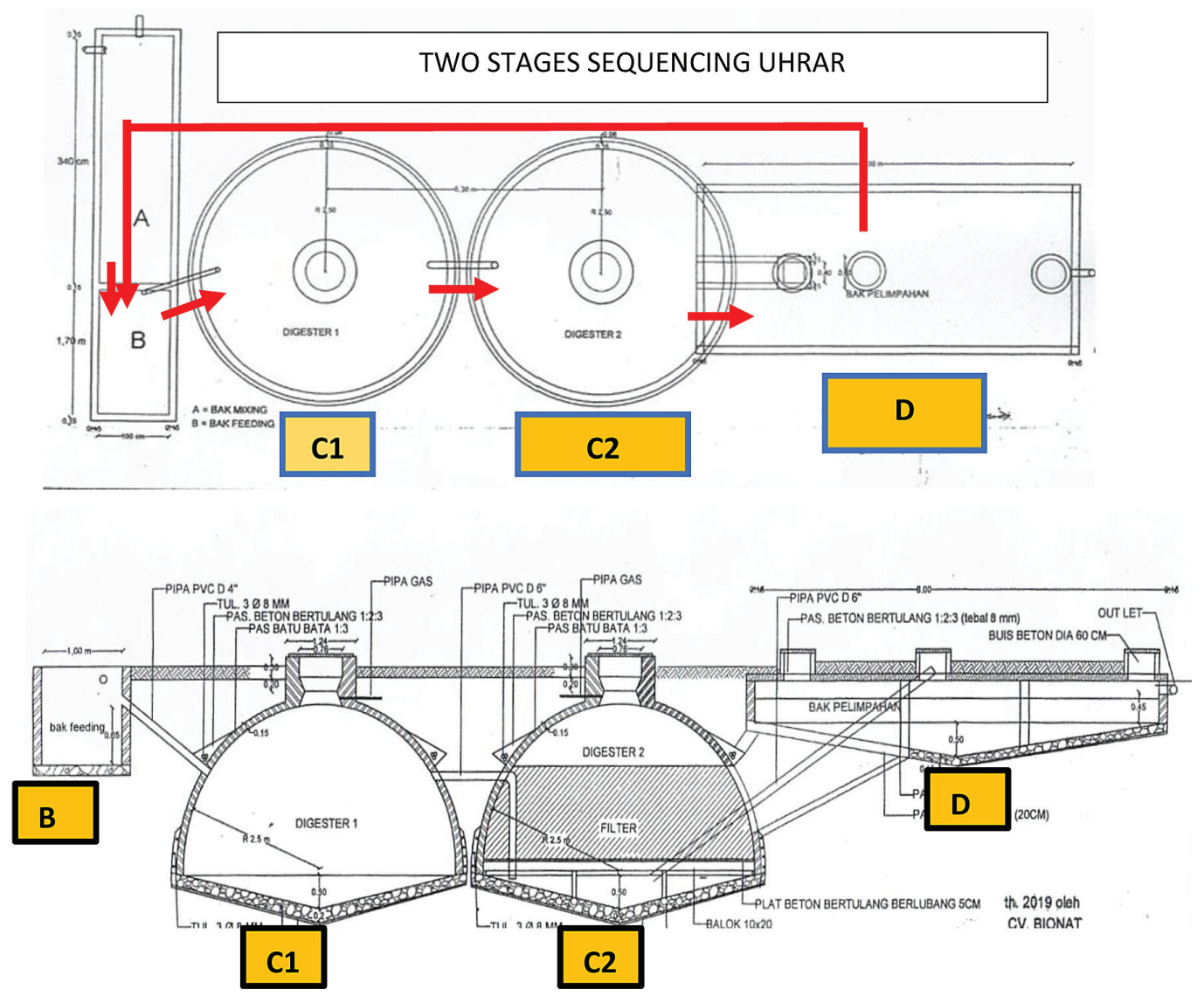

Legends:

A - mixing chamber $\left(V=3 \mathrm{~m}^{3}\right)$

$B$ - feeding chamber $\left(V=3 \mathrm{~m}^{3}\right)$

C1 - UHRAR dome 1 (without filter) $\left(\mathrm{V}=30 \mathrm{~m}^{3}\right)$

C2 - UHRAR dome 2 (with filters) $\left(V=30 \mathrm{~m}^{3}\right)$

$\mathrm{D}$ - overflow chamber

Figure 1. Design of two stages sequencing UHRAR 
Table 1. Characteristic of Vinasse wastewater influent

\begin{tabular}{|c|c|c|c|c|}
\hline \multirow{2}{*}{ Parameter } & \multirow{2}{*}{ Unit } & \multicolumn{3}{|c|}{ Influent Concentration } \\
\hline & & Day 23 & Day 25 & Day 32 \\
\hline $\mathrm{pH}$ & - & 5.7 & 6.2 & 3.4 \\
\hline COD & $\mathrm{mg} / \mathrm{L}$ & 60,990 & 104,000 & 95,800 \\
\hline $\mathrm{BOD}_{5}$ & $\mathrm{mg} / \mathrm{L}$ & 3,553 & 32,990 & 33,299 \\
\hline TSS & $\mathrm{mg} / \mathrm{L}$ & 3,080 & 5,612 & 5,756 \\
\hline TKN (Total Kjeidahl Nitrogen) & $\mathrm{mg} / \mathrm{L}$ & 224 & 322 & 196 \\
\hline P. Total & $\mathrm{mg} / \mathrm{l}$, & 4.57 & $<0.001$ & $<0.001$ \\
\hline MLVSS & $\mathrm{mg} / \mathrm{L}$ & 3,990 & 9,300 & 7,300 \\
\hline MLSS & $\mathrm{mg} / \mathrm{L}$ & 1,250 & 4,080 & 2,020 \\
\hline Sulphate $\left(\mathrm{SO}_{4}^{2-}\right)$ & $\mathrm{mg} / \mathrm{L}$ & $<0.26$ & $<0.6$ & $<0.6$ \\
\hline Sulfide (S-) & $\mathrm{mq} / \mathrm{L}$ & 8.55 & 6.55 & 12.85 \\
\hline Total Alkalinity & $\mathrm{mg} / \mathrm{L}$ & 9,150 & 12,685 & 10,150 \\
\hline Nitrate $\left(\mathrm{NO}_{3}\right)$ & $\mathrm{mg} / \mathrm{L}$ & $<0.001$ & 22.51 & 8.252 \\
\hline Nitrite $\left(\mathrm{NO}_{2}\right)$ & $\mathrm{mg} / \mathrm{L}$ & $<0.001$ & $<0.001$ & $<0.001$ \\
\hline Total Plate Count & Coloni/mL & $4.4 \times 10^{6}$ & $1.3 \times 10^{8}$ & $3.7 \times 10^{7}$ \\
\hline Temperature $\left({ }^{\circ} \mathrm{C}\right)$ & ${ }^{\circ} \mathrm{C}$ & 37.1 & 65.0 & 52.0 \\
\hline
\end{tabular}

C2). From UHRAR, wastewater overflowed to the overflow chamber (D). On day 24 to 32 , $25 \%$ of the effluent in the overflow chamber was circulated back to the feeding chamber (Figure 1, from D to B).

The vinasse influent wastewater characteristic during full-scale application in the continuous running was measured. The quality parameters of vinasse wastewater influent are presented in Table 1.

\section{Method}

The vinasse wastewater quality parameters were analyzed by using the analytical method:

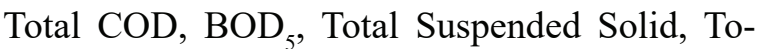
tal Nitrogen Kjeidahl, MLVSS, MLSS, Nitrate, Nitrite, Sulfate, sulfide and phosphate using APHA AWWA $22^{\text {rd }}, 2012$, temperature (SNI 066989.23-2005) and pH (SNI 6989.11.2019). TPC (Total Plate Count) were measured using SNI 3554:2015 point 3.28.1. VFA was measured using Gas Chromatography (Shimadzu, GC 2100 plus), column RTX-wax. Temperature SPL:250, Column: 150, Detector FID: 250, RT $7.5 \mathrm{~min}$, and split ratio 43.2. Gases (methane, $\mathrm{CO}_{2}$, and $\mathrm{CO}$ ) were measured using Gas Chromatography (HP 5890 A), with Thermal Conductivity Detector (TCD), diameter column: $183 \times 0.32 \mathrm{~cm} . \mathrm{H}_{2} \mathrm{~S}$ gas was measured using Ion Science PhoCheck 1000 Portable Handheld PID VOC Gas Detector. Gas Flowrate was measured using the Wet Gas Meter (Shinagawa) $5 \mathrm{~L} / \mathrm{rev}$.

\section{RESULTS AND DISCUSSION}

\section{Batch experiment}

Batch experiment (BMP test) was carried out under two conditions, namely: one sample was undiluted and 3 samples were diluted. The undiluted sample had $\mathrm{pH}$ adjusted to $\mathrm{pH} 6$ by adding lime. Three samples were diluted with water, with ratio water: vinasse $=4: 1$, and $\mathrm{pH}$ was adjusted from 3 to 5, 6 and 7. The result was presented in Table 2.

Table 2 depicted the COD degradation profile and $\mathrm{pH}$ variation from the undiluted and diluted samples. Figure 2 showed that on day 11, at least $50 \%$ COD removal was achieved on the diluted samples. In contrast, on the undiluted sample, only $32 \%$ COD removal occurred. On diluted samples, maximum COD removals were $68 \%(\mathrm{pH} 7) ; 65.7 \%(\mathrm{pH} 6)$ and $70.1 \%(\mathrm{pH} 5)$ respectively. In turn, on the undiluted sample, only $33.5 \%$ of COD removal was achieved. The diluted samples had higher organic removal efficiency due to the increase of a dissolved organic fraction of the samples. Dissolved organic matters was more available to the microorganisms and easier to be converted into smaller molecules (hydrolysis stage) that later could be converted into VFA (acidogenesis), acetate (acetogenesis) and methane and carbon dioxide (methanogenesis), as final products (Gharsallah, 1994; Park et al., 2018).

The $\mathrm{pH}$ and alkalinity have a significant role in organic conversion into methane. 
Table 2. COD degradation profile versus $\mathrm{pH}$

\begin{tabular}{|c|c|c|c|c|c|c|c|c|c|c|c|c|}
\hline \multirow{2}{*}{ Day } & \multicolumn{3}{|c|}{$\mathrm{pH} 6$ (undiluted) } & \multicolumn{4}{c|}{$\mathrm{pH} 7$} & \multicolumn{3}{c|}{$\mathrm{pH} \mathrm{6}$} & \multicolumn{3}{c|}{$\mathrm{pH} 5$} \\
\cline { 2 - 14 } & $\mathrm{pH}$ & $\begin{array}{c}\mathrm{COD} \\
(\mathrm{mg} / \mathrm{L})\end{array}$ & $\begin{array}{c}\text { Cumulative } \\
\% \text { removal }\end{array}$ & $\mathrm{pH}$ & $\begin{array}{c}\mathrm{COD} \\
(\mathrm{mg} / \mathrm{L})\end{array}$ & $\begin{array}{c}\text { Cumulative } \\
\% \text { removal }\end{array}$ & $\mathrm{pH}$ & $\begin{array}{c}\mathrm{COD} \\
(\mathrm{mg} / \mathrm{L})\end{array}$ & $\begin{array}{c}\text { Cumulative } \\
\% \text { removal }\end{array}$ & $\mathrm{pH}$ & $\begin{array}{c}\text { COD } \\
(\mathrm{mg} / \mathrm{L})\end{array}$ & $\begin{array}{c}\text { Cumulative } \\
\% \text { removal }\end{array}$ \\
\hline 0 & 6 & 168,516 & 0 & 7.0 & 34,421 & 0 & 6.0 & 38,499 & 0 & 5.0 & 43,356 & 0 \\
\hline 11 & 6.4 & 113,844 & 32.4 & 6.0 & 17,556 & 49.0 & 6.1 & 19,026 & 50.6 & 5.8 & 19,799 & 54.3 \\
\hline 18 & 6 & 126,877 & 24.7 & 6.7 & 11,787 & 65.8 & 7 & 18,243 & 52.6 & 7.0 & 22,072 & 49.1 \\
\hline 21 & 5.9 & 117,868 & 30.1 & 6.9 & 10,961 & 68.2 & 6.9 & 13,213 & 65.7 & 7.1 & 17,042 & 60.7 \\
\hline 22 & 5,9 & 117,231 & 30.4 & 7.0 & 16,328 & 52.6 & 7.0 & 19,564 & 49.2 & 7.1 & 20,993 & 51.6 \\
\hline 25 & 5.9 & 113,469 & 32.7 & 7.0 & 14,673 & 57.4 & 7.1 & 16,328 & 57.6 & 7.2 & 18,510 & 57.3 \\
\hline 27 & 5.8 & 112,026 & 33.5 & 7.1 & 12,480 & 63.7 & 7.2 & 13,872 & 64.0 & 7,2 & 15,838 & 63.5 \\
\hline 29 & 5.7 & 119,236 & 29.2 & 7.0 & 12,592 & 63.4 & 7.2 & 13,639 & 64.6 & 7.3 & 15,865 & 63.4 \\
\hline 32 & 5.9 & 116,678 & 30.8 & 7.1 & 12,667 & 63.2 & 7.4 & 13,694 & 64.4 & 7.4 & 14,748 & 66.0 \\
\hline 43 & 6 & 122,494 & 27.3 & 7.3 & 12,748 & 63.0 & 7.6 & 13,925 & 63.8 & 7.6 & 14,748 & 66.0 \\
\hline 50 & 5.9 & 124,260 & 26.3 & 7.5 & 12,960 & 62.3 & 7.6 & 13,920 & 63.8 & 7.7 & 12,960 & 70.1 \\
\hline
\end{tabular}

Methanogenic bacteria have strict $\mathrm{pH}$ for optimum growth, around 6.7-7.5 (Chen et al., 2008; Jung et al., 2000; Lukitawesa et al., 2018), and alkalinity has a role, as a $\mathrm{pH}$ buffer, to balance the $\mathrm{pH}$ in the anaerobic in the acidogenesis and acetogenesis phase. Thus, the $\mathrm{pH}$ and alkalinity have to be in sufficient concentration by adding limestone $\left(\mathrm{CaCO}_{3}\right.$ ) (Fuess et al., 2017a). Table 2 showed that in the undiluted sample ( $\mathrm{pH} 6$ undiluted), the $\mathrm{pH}$ was continually dropping from 6 into 5.9, an indication of acidogenesis/acetogenesis phase. In the diluted samples, the $\mathrm{pH}$ escalated into $7.4(\mathrm{pH}$ optimum for methanogenic activity).

Figure 2 depicted the theoretical cumulative methane yields from the undiluted and diluted samples during 43 days observation. Theoretically, methane generation is calculated as $0.35-0.4 \mathrm{~L} \mathrm{CH}_{4}$ per kg COD removal (Djalma Nunes Ferraz Júnior et al., 2016; Harihastuti et al., 2020b). Theoretical methane yield was calculated based on the amount of $\mathrm{kg}$ COD removed from day 0 to day 43 multiplied by $0.35-0.4 \mathrm{~L} \mathrm{CH}_{4}$. On the basis of that calculation, the theoretical methane yield in this study was 7.51-10.64 $\mathrm{L} \mathrm{CH}_{4}$ per $\mathrm{kg}$ COD for diluted vinasse wastewater with $\mathrm{pH}$ adjustment (OLR $=38-40 \mathrm{~kg} \mathrm{COD} / \mathrm{d}$, with COD degradation of $63-66 \%$ during 43 days). The maximum methane yield was $16.11 \mathrm{~L} \mathrm{CH}_{4}$ per $\mathrm{kg} \mathrm{COD}(\mathrm{OLR}=$ $168 \mathrm{~kg} \mathrm{COD} / \mathrm{d}$, average COD degradation was 24-33\%). Even though theoretically the undiluted sample has a higher methane yield than the diluted sample, under real conditions, the $\mathrm{pH}$ in the undiluted sample keeps dropping into acidic condition. Acidic $\mathrm{pH}$ is unfavorable for the methanogenic activity. The COD removal in the undiluted sample has also remained low. Those conditions are an indication of an unbalance system that sooner could deteriorate the reactor performance.

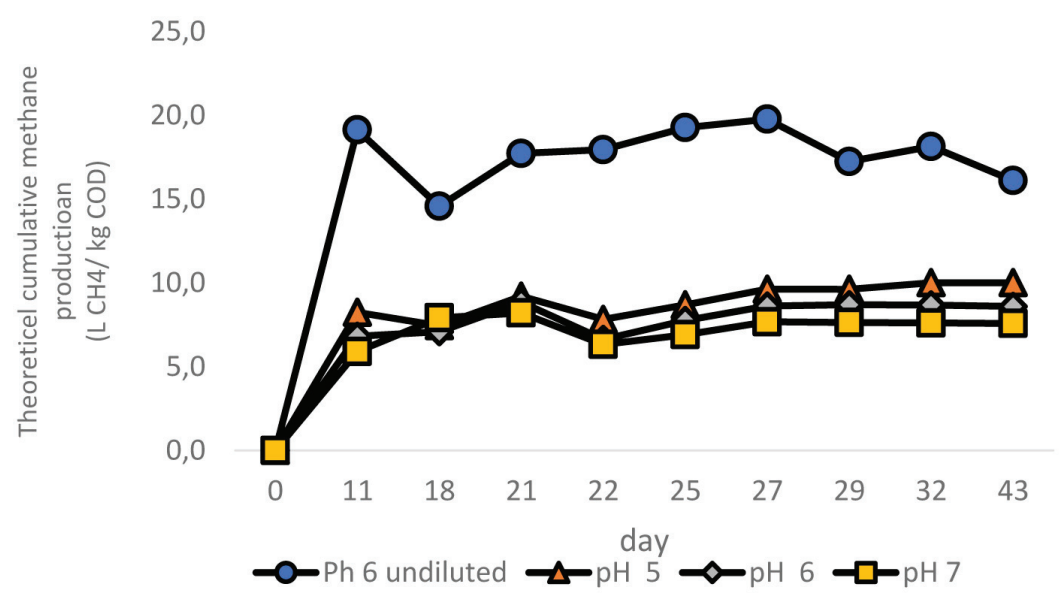

Figure 2. Theoretical methane accumulation from the batch experiment 
Thus, based on the results of the batch experiment, for full-scale application, vinasse influent was diluted with water, $\mathrm{pH}$ adjusted to 5-6, and effluent recirculated. Effluent recirculation was done to return the hydrolysis-acidogenic bacteria in the effluent back to the reactor, to enhance the hydrolysis-acidification process. Microbial diversity of mixed culture in anaerobic digester has to be maintained in order to ensure hydrolysis, acidogenesis, acetogenesis, and methanogenesis reactions happened (Ma et al., 2020). Recirculation had also proven to give a stable performance and higher methane yield (Lukitawesa et al., 2018).

\section{Full-Scale Application}

The full-scale application was carried out in a two-stage Up-flow High Rate Anaerobic reactor (UHRAR), with a volume of $60 \mathrm{~m}^{3}$ and hydraulic retention time of 40 days. The vinasse wastewater influent had COD of $60,990-104,000 \mathrm{mg} / \mathrm{L}$ (with OLR $=60.1-104 \mathrm{~kg} \mathrm{COD} / \mathrm{m}^{3} . \mathrm{d}$ ). The samples were taken periodically. Recirculation was applied on day 25 to day 32 . On day 23, 25, and 32 , COD and VFA from influent and effluent were measured and data was shown in Figures 3 and 4. Figure 3 showed the COD degradation profile of influent and effluent on day 23, 25, and 32. On day 23 , the COD removal was only $52 \%$, then increased to $81 \%$ on day 25 . On day 32 , the COD removal slightly decreased to $72 \%$.

Figure 4 illustrated the VFA formation on day 23,25 and 32. On day 23, butyrate was abundant in the influent with a concentration of $7385 \mathrm{mg} / \mathrm{L}$, while the concentration of acetate and propionate were low. The VFA formation was altered on day 25 and 32. On day 25 and 32, the acetate concentration increased to $6459 \mathrm{mg} / \mathrm{L}$ and $4974 \mathrm{mg} / \mathrm{L}$ respectively, while the butyrate and propionate concentrations were low. Associating between figure 3 and figure 4, it could be concluded that the COD degradation performance was in line with the degree of acetate formation, and also the higher concentration of organic matter that converted into acetate, the higher methane production. The COD removal starts to increase and reached $81 \%$ and $71 \%$ when acetates were at high concentration, at $6.459 \mathrm{mg} / \mathrm{L}$ and $4974 \mathrm{mg} / \mathrm{L}$ on day 23 and 32, respectively. Acetate was a favorable substrate for almost any type of microorganisms, especially for methanogenic bacteria (Lalov et al., 2001).

The higher concentration of butyrate at day 23 indicated that the system was still in the acidogenesis stage. As described by Fuess et al. (2020), vinasse could be converted into butyrate via acidogenesis pathway in dark fermentation, if there are abundant of acidogenesis microorganisms and biohydrogen production in the reactor. The system was shifted into acetate production when recirculation was applied at days 25 and 32 (Figure 4, day 25, and 32). According to Degueurce et al. (2016), the effluent recirculation in anaerobic digester promotes the modification of the biological community, enhanced nutrients availability, and improves the $\mathrm{pH}$ buffering capacity, thus improving and stabilizing the biogas production. As depicted in Table 1, on day 23, the number of microorganisms (expressed as MLVSS and total plate count/ TPC) was also lower than day 25 and day 32 .

Recirculation also enhanced the level of biodegradability in the anaerobic system (Lin and Li, 2017)sequential batch SS-AD gradually reached steady state by 3 runs (30 days/run. Day 23 has lower BOD/COD than day 25 and 32. $\mathrm{BOD} / \mathrm{COD}$ ratio at day 23 was 1: 17 whereas

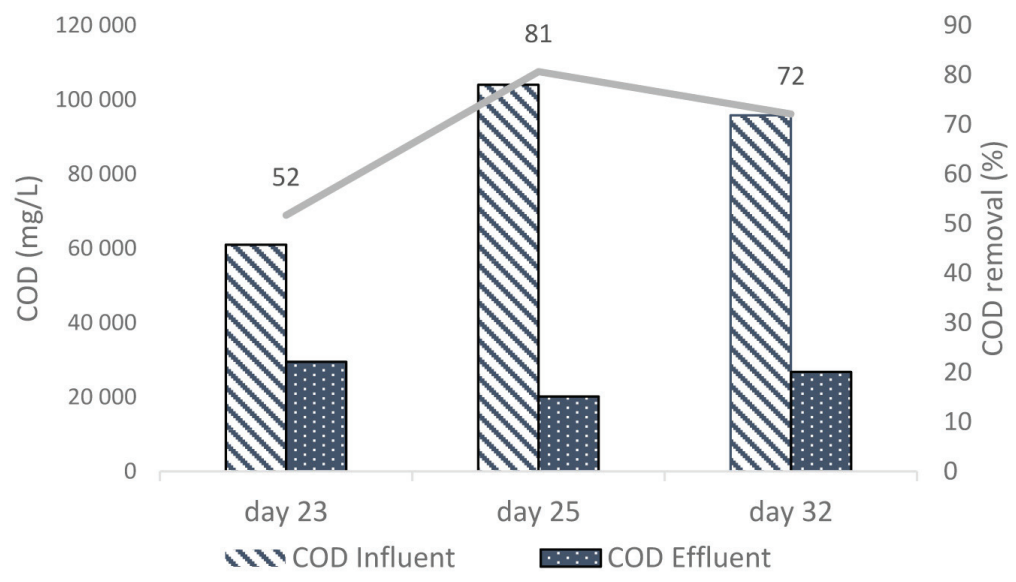

Figure 3. COD degradation in a full-scale application 
Day 23
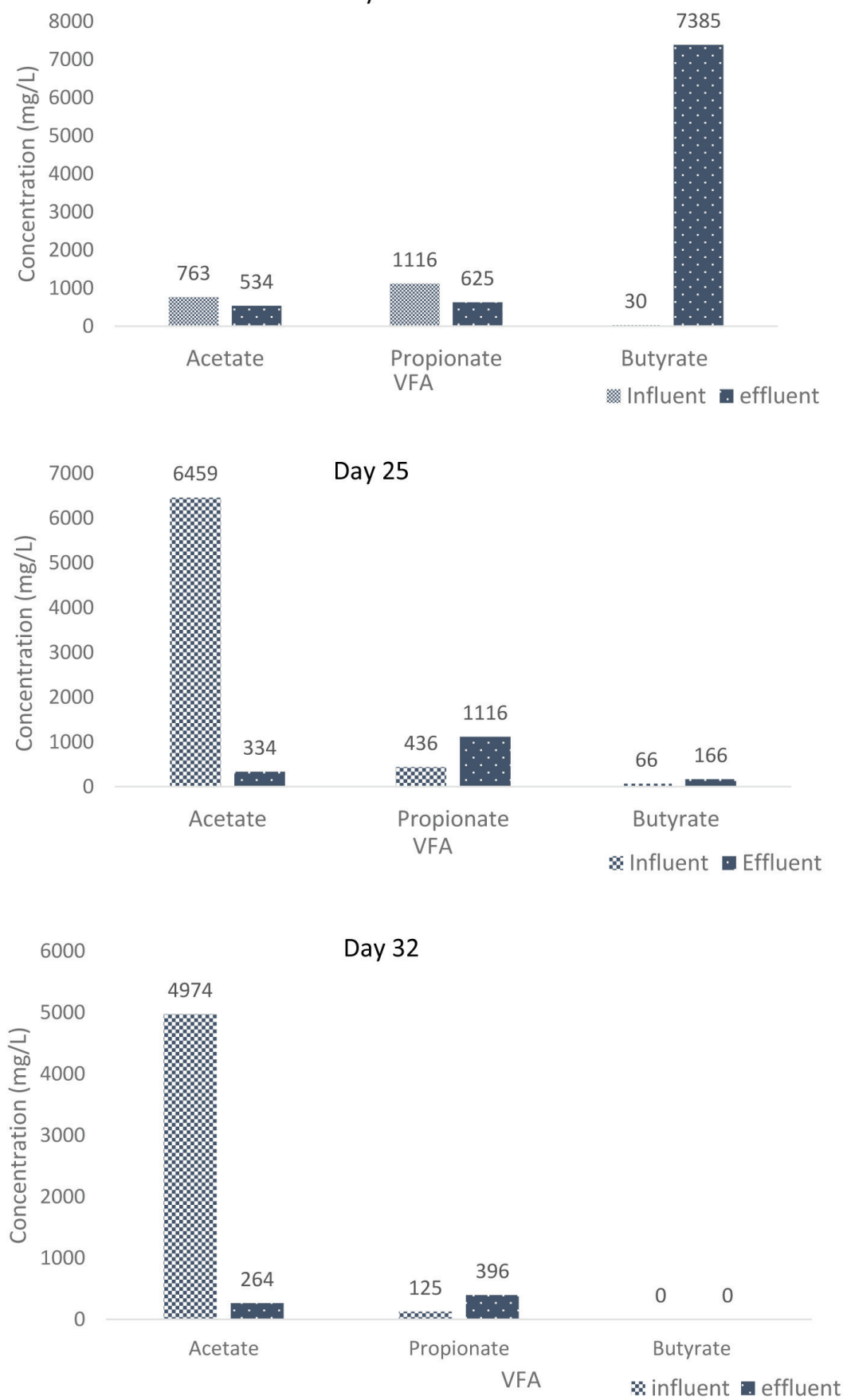

Figure 4 VFA formation on Day 23, 25 and 32

day 25 and 32 that have $\mathrm{BOD} / \mathrm{COD}$ ratio $=1: 3$. $\mathrm{BOD} / \mathrm{COD}$ ratio was an indication of the level of the sample biodegradability. The higher the BOD/COD ratio, the higher the biodegradability of the wastewater is. The addition of lime $\left(\mathrm{CaCO}_{3}\right)$ was proven to be not significantly enhance the buffering capacity of the system, as judging from the condition at day 23, even when $\mathrm{CaCO}_{3}$ was added, the anaerobic system was still trapped in the acidogenesis stage. The anaerobic condition was able to shift into the acetogenesis stage when recirculation was applied at day 25 and 32. The reason is that lime was not properly dissolved in the wastewater and tends to be settled in the bottom of the reactor. Furthermore, the addition of alkaline chemicals, such as $\mathrm{CaCO}_{3}$ or $\mathrm{NaHCO}_{3}$, only slightly increased the $\mathrm{pH}$; thus, it should be added in high dosage and tend to be costly for full-scale application (Fuess et al., 2017a). The better alternative is to use low dosages of chemicals coupled with the recirculation of the effluent (Fuess et al., 2017a). 
The maximum COD degradation of $81 \%$ in this study was relatively higher when compared to a study conducted by Souza et al. (1992) using the UASB reactor. The COD removal was $71 \%$, with lower OLR $\left(25-30 \mathrm{~kg} \mathrm{COD} / \mathrm{m}^{3} . \mathrm{d}\right)$ but faster HRT $(10 \mathrm{~h})$. However, using the UASB reactor was more complicated than using the UHRAR reactor, due to the long startup for granule formation and the need to be continuously fed. For full scale/ real application, UASB needs a very high skilled operator to keep the reactor performance stability. When compared to a study carried out by Fuess et al. (2017b), using a similar two-phase fixed-bed anaerobic reactor, this study was higher, with higher methane production.

\section{Concentration analysis of the vinasse effluent}

Table 3 presents the effluent concentrations that were taken during 32 days of observation, on day 23 , day 25 , and day 32 . Overall, the pollutant concentrations were still high and needed further advance treatment technology to fulfill effluent stream standard regulation (Moraes et al., 2015). It also showed that the nutrient concentrations, TKN, and $\mathrm{P}$, were also still very high. Due to still high content of nutrients (even after effluent recirculation), a suitable way to recover the nutrients is by converting it into organic fertilizer/compost (Madejón et al., 2001; Science, 2007). Hydrogen sulfide $\left(\mathrm{H}_{2} \mathrm{~S}\right)$ was also found in high concentration due to the fact that in the molasses fermentation process, sulfuric acid was added to inhibit the growth of undesirable (nonethanol producing) bacteria that will outcompete the performance of ethanol fermenters (Fuess and Garcia, 2015). A high concentration of $\mathrm{H}_{2} \mathrm{~S}$ is an indication of lower methane production. In microbial mix cultures, Sulfate Reducing Bacteria (SRB) contributes to $80-85 \%$ of the total microorganism population. With abundant amount of $\mathrm{SO}_{4}^{2-}$ as an electron acceptor and acetate as an electron donor, SRB would definitely outcompete the methane-producing bacteria (MPB) by consuming acetate to convert into $\mathrm{SO}_{4}^{2}$ and $\mathrm{H}_{2} \mathrm{~S}$ (Dar et al., 2008), as both SRB and MPB utilize the same substrates. The analysis using $\mathrm{H}_{2} \mathrm{~S}$ gas detection also confirmed that all the biogas samples have very high $\mathrm{H}_{2} \mathrm{~S}$ concentration $(>150 \mathrm{mg} / \mathrm{L})$. However, the $\mathrm{H}_{2} \mathrm{~S}$ concentration seems not to be high enough to inhibit the methanogenic activity. According to Yuan, et al., 2020 (Yuan et al.,
2020), methanogenesis could be inhibited by high sulfide concentration at $\mathrm{COD} / \mathrm{SO}_{4}{ }^{2-}<10$, or $\mathrm{H}_{2} \mathrm{~S}$ could not be higher than $200 \mathrm{mg} / \mathrm{L}$.

\section{Biogas formation in Dome 1, Dome 2, and Dome $(1+2)$}

The reactor was connected to the gas pipe to transfer the gas for further utilization. The gas production was measured by taking samples individually via dome 1 and dome 2, and also taking samples collectively via both dome one plus dome 2 . The biogas production is presented in Table 4. Table 4 showed that the methane production increased along with time, reached maximum on day 25 , and drop slightly on day 32. The methane production profile depicted in table 4 was in line with the COD removal profile presented in figure 4 . The highest methane production occurred on day 25 , with methane detected at dome 1 was $40.22 \%$ and for dome 2 was $43.49 \%$. In turn, the total methane production from Dome 1 and Dome 2 could not be measured due to the high gas pressure in the sample due to the broken sample bottle. Higher gas pressure was suspected to be an indication of higher methane content as well (confirmed by measurement of Qgas $=52 \mathrm{~L} / \mathrm{min})$. Nevertheless, analyzing methane production along with time, depicted in from table 4 , methane production could be as high as $51 \%$. This value was slightly lower than result in BMP/ batch experiment (Table 2), which could achieve a maximum of $63-66 \%$ methane production.

The COD and methane data measured on day 32 were used to measure the methane production $\left(\mathrm{m}^{3} \mathrm{CH}_{4} / \mathrm{kg}\right.$ COD.d), based on Figure 3, Table 4 and measurement of Qgas $=50 \mathrm{~L} / \mathrm{min}$ ). On day 32 , the COD removal was $69.1 \mathrm{~kg} \mathrm{COD} / \mathrm{d}$, whereas the methane production was $36.72 \mathrm{~m}^{3} \mathrm{CH}_{4} /$ d. Thus, the methane production per COD removed was $0.53 \mathrm{~m}^{3} \mathrm{CH}_{4} / \mathrm{kg}$ COD.d. The methane production in this study was 1.5 times higher than the study conducted by Fuess et al., 2017 (Fuess et al., 2017b). In Fuess et al., 2017, using thermophilic two phases anaerobic digestion with OLR of $25 \mathrm{~kg} \mathrm{COD} / \mathrm{m}^{3} . \mathrm{d}$, the maximum COD removal was up to $73.9 \%$, with methane production was $0.301 \mathrm{~m}^{3} \mathrm{CH}_{4} / \mathrm{kg}$ COD removed. This study used Up-flow High Rate Anaerobic Reactor (UHRAR) with OLR $95 \mathrm{~kg} \mathrm{COD} / \mathrm{m}^{3}$.d, COD removal was up to $71 \%$, with methane production reaching $0.53 \mathrm{~m}^{3} \mathrm{CH}_{4} / \mathrm{kg}$ COD.d. 
Table 4. $\mathrm{CH}_{4}, \mathrm{CO}_{2}$, and $\mathrm{CO}$ formation during 32 days observation

\begin{tabular}{|c|c|c|c|c|c|c|c|c|c|}
\hline \multirow{2}{*}{$\begin{array}{c}\text { Days } \\
\text { elapsed }\end{array}$} & \multicolumn{3}{|c|}{ Dome 1 } & \multicolumn{3}{c|}{ Dome 2 } & \multicolumn{3}{c|}{ Dome 1+2 } \\
\cline { 2 - 11 } & $\begin{array}{c}\mathrm{CH} 4 \\
(\%)\end{array}$ & $\begin{array}{c}\mathrm{CO}_{2} \\
(\%)\end{array}$ & $\begin{array}{c}\mathrm{CO} \\
(\mathrm{ppm})\end{array}$ & $\begin{array}{c}\mathrm{CH}_{4} \\
(\%)\end{array}$ & $\begin{array}{c}\mathrm{CO}_{2} \\
(\%)\end{array}$ & $\begin{array}{c}\mathrm{CO} \\
(\mathrm{ppm})\end{array}$ & $\begin{array}{c}\mathrm{CH}_{4} \\
(\%)\end{array}$ & $\begin{array}{c}\mathrm{CO}^{2} \\
(\%)\end{array}$ & $\begin{array}{c}\mathrm{CO} \\
(\mathrm{ppm})\end{array}$ \\
\hline 0 & 8.750 & 38.932 & trace & $\begin{array}{c}\text { not } \\
\text { measured }\end{array}$ & $\begin{array}{c}\text { not } \\
\text { measured }\end{array}$ & $\begin{array}{c}\text { not } \\
\text { measured }\end{array}$ & $\begin{array}{c}\text { not } \\
\text { measured }\end{array}$ & $\begin{array}{c}\text { not } \\
\text { measured }\end{array}$ & $\begin{array}{c}\text { not } \\
\text { measured }\end{array}$ \\
\hline 10 & 22.84 & 7.59 & trace & 23.07 & 12.06 & 212 & 30.00 & 12.4 & 88 \\
\hline 11 & 57.21 & 8.93 & 124 & 48.23 & 10.83 & 79 & 51.58 & 10.7 & $>1000$ \\
\hline 12 & 38.26 & 5.51 & 46.2 & 24.51 & 6.39 & 124 & 37.89 & 6.78 & 84 \\
\hline 23 & 42.38 & 2.37 & $>1000$ & 4.420 & 1.49 & $>1000$ & 42.95 & 23.14 & $>1000$ \\
\hline 25 & 40.22 & 22.95 & 175 & 43.49 & 26.03 & 9 & $\left(^{*}\right)$ & $\left(^{*}\right)$ & 7.63 \\
\hline 32 & 19.45 & 9.29 & 276 & 30.50 & 10.36 & 18 & 51.36 & 14.2 & 7.60 \\
\hline
\end{tabular}

Table 4 also shows the formation of $\mathrm{CO}$ (Carbon Monoxides) as one of common trace components in the anaerobic system. As explained by Hickey and Switzenbaum (1990), $\mathrm{CO}$ was formed as acetate-catabolizing reactions of acetoclastic methanogens, when there are high concentrations of acetate, methane, and hydrogen in the system. The high concentration of $\mathrm{H}_{2} \mathrm{~S}$ gas was also detected due to the high concentration of sulfide $\left(\mathrm{S}^{-}\right)$in the influent, coupled with the abundance of SRB, which consumes the same substrate as methanogen, leading to the formation of $\mathrm{H}_{2} \mathrm{~S}$.

\section{CONCLUSIONS}

Substrate modification and effluent recirculation has been shown to increase the organic degradation and methane generation of vinasse wastewater with high OLR. Substrate modification by adding $\mathrm{CaCO}_{3}$ was able to enhance alkalinity, and thus stabilize the $\mathrm{pH}$. In turn, effluent recirculation was proven to increase substrate biodegradability by enhancing the solid organic matter solubility. On the basis of this result, fullscale application with high OLR, using UHRAR combined with substrate modification and effluent recirculation, is a promising technology for biogas generation from vinasse wastewater.

\section{Acknowledgment}

This research was supported by the Centre of Industrial Pollution Prevention Technology, Ministry of Industry of the Republic of Indonesia. The authors would like to say thank to Saifuddin for the laboratory assistance, and Agus Sariyanto for providing resources for full-scale application.

\section{REFERENCES}

1. Cabrera-Díaz, A., Pereda-Reyes, I., Oliva-Merencio, D., Lebrero, R., Zaiat, M. 2017. Anaerobic Digestion of Sugarcane Vinasse Through a Methanogenic UASB Reactor Followed by a Packed Bed Reactor. Appl. Biochem. Biotechnol, 183, 1127-1145. https://doi.org/10.1007/s12010-017-2488-2

2. Chen, Y., Cheng, J.J., Creamer, K.S. 2008. Inhibition of anaerobic digestion process: A review. Bioresour. Technol, 99, 4044-4064. https://doi.org/10.1016/j. biortech.2007.01.057

3. Christofoletti, C.A., Escher, J.P., Correia, J.E., Marinho, J.F.U., Fontanetti, C.S., 2013. Sugarcane vinasse: Environmental implications of its use. Waste Manag, 33, 2752-2761. https://doi. org/10.1016/j.wasman.2013.09.005

4. Dar, S.A., Kleerebezem, R., Stams, A.J.M., Kuenen, J.G., Muyzer, G., 2008. Competition and coexistence of sulfate-reducing bacteria, acetogens and methanogens in a lab-scale anaerobic bioreactor as affected by changing substrate to sulfate ratio. Appl. Microbiol. Biotechnol, 78, 1045-1055. https://doi. org/10.1007/s00253-008-1391-8

5. Degueurce, A., Tomas, N., Le Roux, S., Martinez, J., Peu, P., 2016. Biotic and abiotic roles of leachate recirculation in batch mode solid-state anaerobic digestion of cattle manure. Bioresour. Technol, 200, 388-395. https://doi.org/10.1016/j. biortech.2015.10.060

6. Del Nery, V., Alves, I., Zamariolli Damianovic, M.H.R., Pires, E.C., 2018. Hydraulic and organic rates applied to pilot scale UASB reactor for sugar cane vinasse degradation and biogas generation. Biomass and Bioenergy, 119, 411-417. https://doi. org/10.1016/j.biombioe.2018.10.002

7. Djalma Nunes Ferraz Júnior, A., Koyama, M.H., de Araújo Júnior, M.M., Zaiat, M., 2016. Thermophilic anaerobic digestion of raw sugarcane vinasse. Renew. Energy, 89, 245-252. https://doi.org/10.1016/j. renene. 2015.11 .064 
8. Drtil, M., Bod, I., Herdov, B., 2002. The use of upflow anaerobic filter and AnSBR for wastewater treatment at ambient temperature 36, 1084-1088.

9. Fuess, L.T., de Araújo Júnior, M.M., Garcia, M.L., Zaiat, M., 2017a. Designing full-scale biodigestion plants for the treatment of vinasse in sugarcane biorefineries: How phase separation and alkalinization impact biogas and electricity production costs? Chem. Eng. Res. Des, 119, 209-220. https://doi. org/10.1016/j.cherd.2017.01.023

10. Fuess, L.T., dos Santos, G.M., Delforno, T.P., de Souza Moraes, B., da Silva, A.J., 2020. Biochemical butyrate production via dark fermentation as an energetically efficient alternative management approach for vinasse in sugarcane biorefineries. Renew. Energy, 158, 3-12. https://doi.org/10.1016/j. renene.2020.05.063

11. Fuess, L.T., Garcia, M.L., 2015. Bioenergy from stillage anaerobic digestion to enhance the energy balance ratio of ethanol production. J. Environ. Manage, 162, 102-114. https://doi.org/10.1016/j. jenvman.2015.07.046

12. Fuess, L.T., Kiyuna, L.S.M., Ferraz, A.D.N., Persinoti, G.F., Squina, F.M., Garcia, M.L., Zaiat, M., 2017b. Thermophilic two-phase anaerobic digestion using an innovative fixed-bed reactor for enhanced organic matter removal and bioenergy recovery from sugarcane vinasse. Appl. Energy, 189, 480-491. https://doi.org/10.1016/j. apenergy.2016.12.071

13. Gharsallah, N., 1994. Influence of dilution and phase separation on the anaerobic digestion of olive mill wastewaters. Bioprocess Eng, 10, 29-34. https://doi.org/10.1007/BF00373532

14. Harihastuti, N., Marlena, B., 2018. Bioenergy Potential Based on Vinasse from Ethanol Industrial Waste to Green Energy Sustainability. E3S Web Conf, 31, 2017-2019. https://doi.org/10.1051/ e3sconf $/ 20183102015$

15. Harihastuti, N., Marlena, B., Irnaning, N.H., Yuliasni, R., 2020. Decomposition process of stilage/vinasse organic compound from ethanol industry as renewable energy source, AIP Conf. Proc. 2197, 3-8. https://doi.org/10.1063/1.5140897

16. Hickey, R.F., Switzenbaum, M.S., 1990. Behavior of Carbon Monoxide as a Trace Component of Anaerobic Digester Gases and Methanogenesis from Acetate. Environ. Sci. Technol, 24, 1642-1648. https://doi.org/10.1021/es00081a003

17. Hwang, M.H., Jang, N.J., Hyun, S.H., Kim, I.S., 2004. Anaerobic bio-hydrogen production from ethanol fermentation: the role of $\mathrm{pH}$. J. Biotechnol, 111, 297-309. https://doi.org/10.1016/j. jbiotec.2004.04.024

18. Joppert, C.L., dos Santos, M.M., Costa, H.K.M., dos Santos, E.M., Moreira Simões, J.R., 2017. Energetic shift of sugarcane bagasse using biogas produced from sugarcane vinasse in Brazilian ethanol plants. Biomass and Bioenergy 107, 63-73. https://doi. org/10.1016/j.biombioe.2017.09.011

19. Jung, J.Y., Lee, S.M., Shin, P.K., Chung, Y.C., 2000. Effect of $\mathrm{pH}$ on phase separated anaerobic digestion. Biotechnol. Bioprocess Eng, 5, 456-459. https:// doi.org/10.1007/bf02931947

20. Lalov, I.G., Krysteva, M.A., Phelouzat, J.L., 2001. Improvement of biogas production from vinasse via covalently immobilized methanogens. Bioresour. Technol, 79, 83-85. https://doi.org/10.1016/ S0960-8524(01)00045-1

21. Li, J., Li, B., Zhu, G., Ren, N., Bo, L., He, J., 2007. Hydrogen production from diluted molasses by anaerobic hydrogen producing bacteria in an anaerobic baffled reactor (ABR). Int. J. Hydrogen Energy, 32, 3274-3283. https://doi.org/10.1016/j. ijhydene.2007.04.023

22. Lin, L., Li, Y., 2017. Sequential batch thermophilic solid-state anaerobic digestion of lignocellulosic biomass via recirculating digestate as inoculum - Part I: Reactor performance. Bioresour. Technol, 236, 186-193. https://doi.org/10.1016/j. biortech.2017.03.136

23. Lukitawesa, Wikandari, R., Millati, R., Taherzadeh, M.J., Niklasson, C., 2018. Effect of effluent recirculation on biogas production using two-stage anaerobic digestion of citrus waste. Molecules, 23, 1-11. https://doi.org/10.3390/molecules23123380

24. Ma, X., Yu, M., Yang, M., Zhang, S., Gao, M., Wu, C., Wang, Q., 2020. Effect of liquid digestate recirculation on the ethanol-type two-phase semicontinuous anaerobic digestion system of food waste. Bioresour. Technol, 313, 123534. https://doi. org/10.1016/j.biortech.2020.123534

25. Madejón, E., López, R., Murillo, J.M., Cabrera, F., 2001. Agricultural use of three ( sugar-beet) vinasse composts : effect on crops and chemical properties of a Cambisol soil in the Guadalquivir river valley (SW Spain), 84, 55-65.

26. Mahajan, R., Chandel, S., Puniya, A.K., Goel, G., 2020. Effect of pretreatments on cellulosic composition and morphology of pine needle for possible utilization as substrate for anaerobic digestion. Biomass and Bioenergy, 141, 105705. https://doi.org/ https://doi.org/10.1016/j.biombioe.2020.105705

27. Marafon, A.C., Salomon, K.R., Amorim, E.L.C., Peiter, F.S., 2020. Use of sugarcane vinasse to biogas, bioenergy, and biofertilizer production, Sugarcane Biorefinery, Technology and Perspectives. Elsevier Inc. https://doi.org/10.1016/ b978-0-12-814236-3.00010-x

28. Moraes, B.S., Zaiat, M., Bonomi, A., 2015. Anaerobic digestion of vinasse from sugarcane ethanol production in Brazil: Challenges and perspectives. 
Renew. Sustain. Energy Rev. 44, 888-903. https:// doi.org/10.1016/j.rser.2015.01.023

29. Park, J.H., Kumar, G., Yun, Y.M., Kwon, J.C., Kim, S.H., 2018. Effect of feeding mode and dilution on the performance and microbial community population in anaerobic digestion of food waste. Bioresour. Technol. 248, 134-140. https://doi.org/10.1016/j. biortech.2017.07.025

30. Parsaee, M., Kiani Deh Kiani, M., Karimi, K., 2019. A review of biogas production from sugarcane vinasse. Biomass and Bioenergy, 122, 117-125. https://doi.org/10.1016/j.biombioe.2019.01.034

31. Reis, C.E.R., Hu, B., 2017. Vinasse from sugarcane ethanol production: Better treatment or better utilization? Front. Energy Res. 5, 1-7. https://doi. org/10.3389/fenrg.2017.00007

32. Science, W., 2007. Co-composting of distillery and winery wastes with sewage sludge Co-composting of distillery and winery wastes with sewage sludge. https://doi.org/10.2166/wst.2007.488
33. Souza, M.E., Fuzaro, G., Polegato, A.R., 2018. Thermophilic Anaerobic Digestion Of Vinasse In Pilot Plant UASB Reactor, Wat Sci Tech, 25, 213-222.

34. Souza, M.E., Fuzaro, G., Polegato, A.R., 1992. Thermophilic anaerobic digestion of vinasse in pilot plant UASB reactor. Water Sci. Technol, 25, 213-222. https://doi.org/10.2166/wst.1992.0153

35. Yuan, Y., Cheng, H., Chen, F., Zhang, Y., Xu, X., Huang, C., Chen, C., Liu, W., Ding, C., Li, Z., Chen, T., Wang, A., 2020. Enhanced methane production by alleviating sulfide inhibition with a microbial electrolysis coupled anaerobic digestion reactor. Environ. Int. 136, 105503. https://doi.org/10.1016/j. envint.2020.105503

36. Yuliasni, R., Setyaningsih, N.I., Handayani, N.I., Budiarto, A., 2017. The performance of combined technology Upflow anaerobic reactor (UAR)-activated sludge (AS) for treating batik wastewater. Adv. Sci. Lett, 23, 2246-2250. https://doi.org/10.1166/ asl.2017.8725 